\title{
Effect of Iron and Zinc Enriched Organics on Growth, Yield Attributes and Yield of Potato in Loamy Sand
}

\author{
Neha Chaudhary ${ }^{1 *}$, B.T. Patel ${ }^{2}$ and Sweta A. Patel ${ }^{3}$ \\ ${ }^{1}$ Bio Science Research Centre, S. D. Agricultural University, Sardarkrushinagar-385506 \\ (Gujarat), India \\ ${ }^{2}$ Department of Agriculture Chemistry and Soil Science, CPCA, S. D. Agricultural University, \\ Sardarkrushinagar-385506 (Gujarat), India \\ ${ }^{3}$ AICRP on IFS, S. D. Agricultural University, Sardarkrushinagar-385506 (Gujarat), India \\ *Corresponding author
}

\begin{tabular}{|l|}
\hline K e y w o r d s \\
$\begin{array}{l}\text { Iron, Zinc, FYM, } \\
\text { Vermicompost, } \\
\text { Potato, Yield }\end{array}$ \\
\hline Article Info \\
\hline $\begin{array}{l}\text { Accepted: } \\
\text { 10 July 2019 } \\
\text { Available Online: } \\
\text { 10 August } 2019\end{array}$ \\
\hline
\end{tabular}

A B S T R A C T

A field experiment was conducted at the Agronomy Instructional Farm, Department of Agronomy, Chimanbhai Patel College of Agriculture, Sardarkrushinagar Dantiwada Agricultural University, Sardarkrushinagar to study the effect of $\mathrm{Fe}$ and $\mathrm{Zn}$ enriched organics on growth, yield attributes and yield of potato in loamy sand (Typic Ustipsamments) during the rabi seasons of 2016-17 and 2017-18. The pooled results revealed that an application of $5 \mathrm{t}$ vermicompost $\mathrm{ha}^{-1}$ recorded significantly higher plant height at 90 DAP, number of tubers per plant, total tuber yield, haulm yield and dry weight of tuber as compared to $20 \mathrm{t} \mathrm{FYM} \mathrm{ha}^{-1}$. An application of organics $2 \mathrm{t} \mathrm{ha}^{-1}$ enriched with $6 \mathrm{~kg} F e$ and $4 \mathrm{~kg} \mathrm{Zn}$ recorded significantly higher growth, yield attributes and yield viz., plant height 90 DAP, number of tubers per plant, medium and large size tuber yield, total tuber yield, haulm yield and dry weight of tuber as compared to no application of $\mathrm{Fe}$ and $\mathrm{Zn}$ (control).

\section{Introduction}

Micronutrient deficiencies in Indian soils and crops have been on the increase since the adoption of modern agricultural technology with increased use of NPK fertilizers generally free from micronutrients, intensive cultivation with fertilizer responsive improved varieties of crops with more irrigation facilities, limited use of organic manure and restricted recycling of crop residues (Prasad, 1999). On the basis of 7587 soil samples collected from different districts of Gujarat, it was found that 25.9 and 25.6 per cent samples were deficient in Fe and Zn, respectively (Patel et al., 2018). Desai et al., (2018) collected 556 soil samples from different talukas of Banaskantha district and found that 34.8 and 37.6 per cent samples 
were deficient in $\mathrm{Fe}$ and $\mathrm{Zn}$, respectively. Iron and zinc deficiencies are common micronutrient deficiency in light textured soils of North Gujarat limiting both crop production and nutritional quality. The productivity could be sustained through integration use of organics with inorganic fertilizers. Supplementation of deficient nutrients is necessary for higher crop yields. Approximately 40 per cent of the world's populations suffer from micronutrient deficiencies, including $\mathrm{Fe}$ and $\mathrm{Zn}$ deficiency

Potato is an important crop of North Gujarat particularly in Banaskantha district. The process of enrichment of organics with $\mathrm{Fe}$ and Zn not only increase crop yield but also helps in reducing the load of inorganic chemicals as well as quantity of organics to a considerable extent (Meena et al., 2006). The information on $\mathrm{Fe}$ and $\mathrm{Zn}$ enriched organics (FYM/Vermicompost) is lacking on Fe and $\mathrm{Zn}$ deficient soils of Banaskantha of North Gujarat where potato crop is grown. Present study was conducted to assess the Fe and $\mathrm{Zn}$ enriched organics on growth, yield attributes and yield of potato crop.

\section{Materials and Methods}

A field experiment was conducted at the Agronomy Instructional Farm, Department of Agronomy, Chimanbhai Patel College of Agriculture, Sardarkrushinagar Dantiwada Agricultural University, Sardarkrushinagar during the rabi seasons of 2016-17 and 201718 to study the effect of $\mathrm{Fe}$ and $\mathrm{Zn}$ enriched organics on growth, yield attributed and yield of potato. The soil of the experimental plot was loamy sand in texture, low in organic carbon, available N and DTPA-extractable Fe and $\mathrm{Zn}$; medium in available $\mathrm{P}_{2} \mathrm{O}_{5}, \mathrm{~K}_{2} \mathrm{O}$ and $\mathrm{S}$ whereas high in DTPA-extractable $\mathrm{Mn}$ and $\mathrm{Cu}$ content. Twelve treatment combinations comprising of two organics viz., $20 \mathrm{t} \mathrm{FYM} \mathrm{ha}^{-1}$ $\left(\mathrm{M}_{1}\right)$ and $5 \mathrm{t}$ vermicompost $\mathrm{ha}^{-1}\left(\mathrm{M}_{2}\right)$ and six treatments of $\mathrm{Fe}$ and $\mathrm{Zn}$ supplementation viz., No Fe and $\mathrm{Zn}\left(\mathrm{N}_{1}\right), 6 \mathrm{~kg} \mathrm{Fe}$ and $4 \mathrm{~kg} \mathrm{Zn} \mathrm{ha}{ }^{-1}$ (Inorganic) $\left(\mathrm{N}_{2}\right)$, organics $2 \mathrm{t} \mathrm{ha}^{-1}$ enriched with $3 \mathrm{~kg} \mathrm{Fe}\left(\mathrm{N}_{3}\right)$, organics $2 \mathrm{t} \mathrm{ha}^{-1}$ enriched with $2 \mathrm{~kg} \mathrm{Zn}\left(\mathrm{N}_{4}\right)$, organics $2 \mathrm{tha}^{-1}$ enriched with $6 \mathrm{~kg} \mathrm{Fe}$ and $4 \mathrm{~kg} \mathrm{Zn}\left(\mathrm{N}_{5}\right)$ and organics $2 \mathrm{t}$ $\mathrm{ha}^{-1}$ enriched with $3 \mathrm{~kg} \mathrm{Fe}$ and $2 \mathrm{~kg} \mathrm{Zn}\left(\mathrm{N}_{6}\right)$ were laid out under factorial randomized block design with four replications. The enrichment process was started 45 days before their use in rabi experiment (2016-17 and 2017-18) on potato. The required quantities of organics (FYM and vermicompost) were filled in the pre-dug pit of $1.0 \times 1.0 \times 1.0 \mathrm{~m}^{3}$ size. The FYM and vermicompost were thoroughly mixed with the solution of $\mathrm{FeSO}_{4} \cdot 7 \mathrm{H}_{2} \mathrm{O}$ and $\mathrm{ZnSO}_{4} .7 \mathrm{H}_{2} \mathrm{O}$ having required concentration as per treatments viz., $3 \mathrm{~kg} \mathrm{Fe}, 2 \mathrm{~kg} \mathrm{Zn,} 6 \mathrm{~kg} \mathrm{Fe}$ and $4 \mathrm{~kg} \mathrm{Zn}$ and $3 \mathrm{~kg} \mathrm{Fe}$ and $2 \mathrm{~kg} \mathrm{Zn}$ through 2 tonnes of organics (FYM and vermicompost) per hectare. The moisture percentage of FYM and vermicompost after mixing with $\mathrm{FeSO}_{4} .7 \mathrm{H}_{2} \mathrm{O}$ and $\mathrm{ZnSO}_{4} \cdot 7 \mathrm{H}_{2} \mathrm{O}$ were kept at about 75 to 80 . The starter inoculums of microorganisms in the form of cow dung slurry @1\% was applied to boostup the microbiological activities for enrichment of natural process of composting to fix the externally added inorganic $\mathrm{Fe}$ and $\mathrm{Zn}$ into organically bound and naturally chelated form of $\mathrm{Fe}$ and $\mathrm{Zn}$. The pit was covered with polythene sheet and allowed for decomposition. The mixture was turned over periodically (weekly) and moisture loss was maintained. The data for total $\mathrm{Fe}$ and $\mathrm{Zn}$ content of FYM and vermicompost before and after enrichment are given in Table 1 . The Fe and $\mathrm{Zn}$ enriched organics were used in a field experiment.

Farm yard manure @ 20 t ha ${ }^{-1}$ and vermicompost @ $5 \mathrm{t} \mathrm{ha}^{-1}$ were manually applied in previously opened furrows as per treatment in both the years. The entire quantity of phosphorus (137.5 kg ha ${ }^{-1}$ ) and potassium (275 kg ha ${ }^{-1}$ ) whereas, half quantity of 
nitrogen (137.5 $\left.\mathrm{kg} \quad \mathrm{ha}^{-1}\right)$ were applied uniformly in opened furrows in the form of diammonium phosphate, muriate of potash and ammonium sulphate, respectively. The required quantity of $\mathrm{Fe}$ and $\mathrm{Zn}$ in the form of $\mathrm{FeSO}_{4} .7 \mathrm{H}_{2} \mathrm{O}(19 \% \mathrm{Fe})$ and $\mathrm{ZnSO}_{4} \cdot 7 \mathrm{H}_{2} \mathrm{O}(21$ $\% \mathrm{Zn})$ were applied in furrow, respectively. After that, application of $\mathrm{Fe}, \mathrm{Zn}$ and $\mathrm{Fe}+\mathrm{Zn}$ enriched FYM or vermicompost @ $2 \mathrm{t} \mathrm{ha}^{-1}$ were applied in furrows as per the treatments. Light planking was done after basal application of fertilizers. The remaining half dose of nitrogen (137.5 kg ha ${ }^{-1}$ ) was top dressed in the form of urea at 45 days after planting.

Potato tubers of variety Kufri Pukhraj was used as test crop and planted on $19^{\text {th }}$ November and $16^{\text {th }}$ November during 2016 and 2017, respectively by keeping inter and intra spacing of $50 \mathrm{~cm}$ and $20 \mathrm{~cm}$ with seed rate of $3000 \mathrm{~kg} \mathrm{ha}^{-1}$. Post sowing cultural operations was taken as per recommended package of practices for potato. The observation on growth and yield attributes such as plant height at 60 and 90 DAP and number of tubers per plant was recorded from five randomly selected potato plants from each net plot at physiological maturity stage. Gradewise tuber yield of potato were recorded at harvest from whole produce of each net plot. Thereafter, it was converted into tones per hectare. After complete drying the haulm was weighed in weighed in kilogram per net plot. Thereafter, it was converted into quintals per hectare.

\section{Results and Discussion}

\section{Growth and yield attributes}

The pooled data presented in Table 3 revealed that different organics as well as Fe and $\mathrm{Zn}$ supplementation did not exert any significant influence on plant population per meter row length at harvest. The results clearly indicated that plant populations per meter row length in experimental plot were uniform. Hence, various growth and yield attributes as well as yield of potato crop was not influenced due to variation in plant population. The pooled results (Table 3) showed that an application of $5 \mathrm{t}$ vermicompost $\mathrm{ha}^{-1}$ recorded significantly higher plant height at 90 DAP and number of tubers per plant as compared to $20 \mathrm{t} \mathrm{FYM} \mathrm{ha}^{-1}$. The magnitude of increase in plant height and number of tubers per plant due to $5 \mathrm{t}$ vermicompost $\mathrm{ha}^{-1}$ was 10.45 and 25.96 per cent over $20 \mathrm{t} \mathrm{FYM} \mathrm{ha}^{-1}$, respectively. The beneficial effect of vermicompost on plant height and number of tubers per plant observed in present study could be attributed to the fact that vermicompost improves the physical and chemical properties of soil and its contribution in supplying of almost all the essential plant nutrients for growth and development of plants and increasing the availability of native soil nutrients due to increase microbial activity.

Thus, balanced nutrition under favourable environment might have helped in production of new tissues and development of new shoots and tubers might have ultimately increased plant height and number of tubers per plant. The results are in agreement with those reported by Channabasana et al., (2008) and Singh et al., (2014).

Among different treatments of $\mathrm{Fe}$ and $\mathrm{Zn}$ supplementation, an application of organics $2 \mathrm{t}$ $\mathrm{ha}^{-1}$ enriched with $6 \mathrm{~kg} \mathrm{Fe}$ and $4 \mathrm{~kg} \mathrm{Zn}$ recorded significantly higher plant height at 90 DAP and number of tubers per plant as compared to other treatments but it was at par with treatment receiving organics $2 \mathrm{t} \mathrm{ha}^{-1}$ enriched with $3 \mathrm{~kg} \mathrm{Fe}$ and $2 \mathrm{~kg} \mathrm{Zn}$. An increase in number of tubers per plant due to application of organics $2 \mathrm{tha}^{-1}$ enriched with 6 $\mathrm{kg} \mathrm{Fe}$ and $4 \mathrm{~kg} \mathrm{Zn}$ was to the tune of 27.36 per cent over control. The observed significant increase in plant height and number of tubers 
per plant under treatment of organics $2 \mathrm{t} \mathrm{ha}^{-1}$ enriched with either $6 \mathrm{~kg} \mathrm{Fe}$ and $4 \mathrm{~kg} \mathrm{Zn}$ or 3 $\mathrm{kg}$ Fe and $2 \mathrm{~kg} \mathrm{Zn}$ could be due to fact that enrichment technique caused mobilization the native nutrients to increase their availability besides addition of $\mathrm{Fe}$ and $\mathrm{Zn}$ in naturally chelated form which are expected to become slowly available to growing crop over longer time (Table 2).

This might helped to balance nutrition of Fe and $\mathrm{Zn}$ besides supplementing other essential plant nutrients and made available to crop for longer time that causes better crop growth and yield attributing characters such as plant height and number of tubers per plant.
The results are in the line of those reported by Rathod et al., (2012), Patel et al., (2016) and Koodi et al., (2017). The interaction effect between organics and $\mathrm{Fe}$ and $\mathrm{Zn}$ supplementation was found significant on number of tubers per plant during both the years as well as in pooled data (Table 4). The significantly the highest number of tubers per plant was recorded under treatment combination of $\mathrm{M}_{2} \mathrm{~N}_{5}$ (5 t vermicompost + vermicompost $2 \mathrm{t} \mathrm{ha}^{-1}$ enriched with $6 \mathrm{~kg} \mathrm{Fe}$ and $4 \mathrm{~kg} \mathrm{Zn}$ ) over rest of treatment combination except treatment combination $\mathrm{M}_{2} \mathrm{~N}_{6}$ (5 t vermicompost $\mathrm{ha}^{-1}+$ vermicompost $2 \mathrm{t} \mathrm{ha}^{-1}$ enriched with $6 \mathrm{~kg} \mathrm{Fe}$ and $4 \mathrm{~kg} \mathrm{Zn}$ ) in pooled results.

\begin{tabular}{|c|c|c|c|c|c|}
\hline \multicolumn{6}{|c|}{ Table.1 Nutrient content of FYM and vermicompost (before enrichment) } \\
\hline \multirow[t]{2}{*}{ Sr. No. } & \multirow{2}{*}{ Parameters } & \multicolumn{2}{|c|}{ FYM } & \multicolumn{2}{|c|}{ Vermicompost } \\
\hline & & 2016-17 & 2017-18 & 2016-17 & 2017-18 \\
\hline 1 & Nitrogen $(\%)$ & 0.61 & 0.58 & 1.55 & 1.52 \\
\hline 2 & Phosphorus (\%) & 0.32 & 0.31 & 1.09 & 1.01 \\
\hline 3 & Potassium $(\%)$ & 0.56 & 0.53 & 0.67 & 0.59 \\
\hline 4 & Iron $\left(\mathrm{mg} \mathrm{kg}^{-1}\right)$ & 3825 & 3510 & 4354 & 4120 \\
\hline 5 & Zinc $\left(\mathrm{mg} \mathrm{kg}^{-1}\right)$ & 90 & 85 & 120 & 108 \\
\hline
\end{tabular}

Table.2 Nutrient content of FYM and vermicompost after enrichment (2016-17 and 2017-18)

\begin{tabular}{|c|c|c|c|c|c|c|c|c|}
\hline \multirow{3}{*}{$\begin{array}{l}\text { Sr. } \\
\text { No. }\end{array}$} & \multirow{3}{*}{$\begin{array}{c}\text { Treatment } \\
\text { combination } \\
\text { code }\end{array}$} & \multirow[t]{3}{*}{ Treatment combinations } & \multicolumn{6}{|c|}{ Chemical parameters } \\
\hline & & & \multicolumn{3}{|c|}{ 2016-17 } & \multicolumn{3}{|c|}{ 2017-18 } \\
\hline & & & $\begin{array}{c}\mathbf{N} \\
(\%)\end{array}$ & $\begin{array}{c}\mathbf{F e} \\
(\mathbf{m g} \\
\left.\mathbf{k g}^{-1}\right)\end{array}$ & $\begin{array}{c}\mathbf{Z n} \\
(\mathbf{m g} \\
\left.\mathrm{kg}^{-1}\right)\end{array}$ & $\begin{array}{c}\mathbf{N} \\
(\%)\end{array}$ & $\begin{array}{c}\mathbf{F e} \\
(\mathbf{m g} \\
\left.\mathrm{kg}^{-1}\right)\end{array}$ & $\underset{(\mathbf{m g} \text { kg }}{\mathbf{Z n}}$ \\
\hline 1 & $\mathbf{M}_{1} \mathbf{N}_{3}$ & FYM $2 \mathrm{t} \mathrm{ha}^{-1}$ enriched with $3 \mathrm{~kg} \mathrm{Fe}$ & 0.62 & 5696 & 110 & 0.61 & 5580 & 97 \\
\hline 2 & $\mathbf{M}_{1} \mathbf{N}_{4}$ & FYM $2 \mathrm{t} \mathrm{ha}^{-1}$ enriched with $2 \mathrm{~kg} \mathrm{Zn}$ & 0.63 & 4040 & 191 & 0.60 & 3990 & 178 \\
\hline 3 & $\mathbf{M}_{1} \mathbf{N}_{5}$ & $\begin{array}{l}\text { FYM } 2 \mathrm{t} \mathrm{ha}^{-1} \text { enriched with } 6 \mathrm{~kg} \text { Fe and } 4 \mathrm{~kg} \\
\mathrm{Zn}\end{array}$ & 0.64 & 8151 & 270 & 0.61 & 8016 & 248 \\
\hline 4 & $\mathbf{M}_{1} \mathbf{N}_{6}$ & $\begin{array}{l}\text { FYM } 2 \mathrm{t} \mathrm{ha}^{-1} \text { enriched with } 3 \mathrm{~kg} \mathrm{Fe} \text { and } 2 \mathrm{~kg} \\
\mathrm{Zn}\end{array}$ & 0.63 & 5848 & 204 & 0.62 & 5710 & 210 \\
\hline 5 & $\mathbf{M}_{2} \mathbf{N}_{3}$ & Vermicompost $2 \mathrm{t} \mathrm{ha}^{-1}$ enriched with $3 \mathrm{~kg} \mathrm{Fe}$ & 1.66 & 6350 & 150 & 1.62 & 6260 & 144 \\
\hline 6 & $\mathbf{M}_{2} \mathbf{N}_{4}$ & Vermicompost $2 \mathrm{t} \mathrm{ha}^{-1}$ enriched with $2 \mathrm{~kg} \mathrm{Zn}$ & 1.64 & 4580 & 225 & 1.61 & 4470 & 212 \\
\hline 7 & $\mathbf{M}_{2} \mathbf{N}_{5}$ & $\begin{array}{l}\text { Vermicompost } 2 \mathrm{tha}^{-1} \text { enriched with } 6 \mathrm{~kg} \mathrm{Fe} \\
\text { and } 4 \mathrm{~kg} \mathrm{Zn}\end{array}$ & 1.69 & 8810 & 395 & 1.65 & 8780 & 381 \\
\hline 8 & $\mathbf{M}_{2} \mathbf{N}_{6}$ & $\begin{array}{l}\text { Vermicompost } 2 \mathrm{tha}^{-1} \text { enriched with } 3 \mathrm{~kg} \mathrm{Fe} \\
\text { and } 2 \mathrm{~kg} \mathrm{Zn}\end{array}$ & 1.62 & 6480 & 230 & 1.62 & 6315 & 223 \\
\hline
\end{tabular}


Table.3 Plant population per meter row length, plant height at 90 DAP, number of tubers per plant, total tuber yield and haulm yield of potato as influenced by different organics and Fe and $\mathrm{Zn}$ supplementation

\begin{tabular}{|c|c|c|c|c|c|}
\hline Treatments & $\begin{array}{c}\text { Plant population } \\
\text { (per meter row length) }\end{array}$ & $\begin{array}{l}\text { Plant height } \\
\text { (cm) }\end{array}$ & $\begin{array}{l}\text { Number of tubers } \\
\text { per plant }\end{array}$ & $\begin{array}{l}\text { Total tuber yield } \\
\qquad\left(\mathrm{t} \mathrm{ha}^{-1}\right)\end{array}$ & $\begin{array}{l}\text { Haulm yield } \\
\qquad\left(\mathbf{q} \mathbf{h a}^{-1}\right)\end{array}$ \\
\hline \multicolumn{6}{|l|}{ Organics (M) } \\
\hline$M_{1}:$ FYM @ 20 t ha $^{-1}$ & 5.58 & 44.0 & 7.28 & 31.309 & 17.96 \\
\hline $\mathbf{M}_{2}:$ Vermicompost @ $5 \mathrm{t} \mathrm{ha}^{-1}$ & 5.70 & 48.6 & 9.17 & 36.274 & 20.90 \\
\hline S.Em. \pm & 0.06 & 0.56 & 0.10 & 0.297 & 0.24 \\
\hline C.D. $(P=0.05)$ & NS & 1.58 & 0.28 & 0.838 & 0.68 \\
\hline \multicolumn{6}{|l|}{ Fe and $\mathrm{Zn}$ supplementation $(\mathrm{N})$} \\
\hline $\mathrm{N}_{1}:$ No Fe and $\mathrm{Zn}$ & 5.42 & 40.5 & 7.09 & 30.167 & 16.79 \\
\hline $\begin{array}{l}\mathrm{N}_{2}: 6 \mathrm{~kg} \mathrm{Fe} \text { and } 4 \mathrm{~kg} \mathrm{Zn} \mathrm{ha}{ }^{-1} \\
\text { (Inorganic) }\end{array}$ & 5.58 & 44.5 & 7.96 & 31.832 & 18.14 \\
\hline $\begin{array}{l}N_{3} \text { :Organics } 2 \mathrm{t} \mathrm{ha}^{-1} \text { enriched } \\
\text { with } 3 \mathrm{~kg} \mathrm{Fe}\end{array}$ & 5.60 & 45.3 & 8.22 & 33.138 & 19.28 \\
\hline $\begin{array}{l}\mathrm{N}_{4} \text { :Organics } 2 \mathrm{t} \mathrm{ha}^{-1} \text { enriched } \\
\text { with } 2 \mathrm{~kg} \mathrm{Zn}\end{array}$ & 5.70 & 46.3 & 8.27 & 33.750 & 19.59 \\
\hline $\begin{array}{l}N_{5} \text { :Organics } 2 \mathrm{t} \mathrm{ha}^{-1} \text { enriched } \\
\text { with } 6 \mathrm{~kg} \text { Fe and } 4 \mathrm{~kg} \mathrm{Zn}\end{array}$ & 5.79 & 51.5 & 9.03 & 37.134 & 22.15 \\
\hline $\begin{array}{l}\mathrm{N}_{6} \text { :Organics } 2 \mathrm{t} \mathrm{ha}^{-1} \text { enriched } \\
\text { with } 3 \mathrm{~kg} \mathrm{Fe} \text { and } 2 \mathrm{~kg} \mathrm{Zn}\end{array}$ & 5.76 & 49.6 & 8.77 & 36.729 & 20.63 \\
\hline S.Em. \pm & 0.10 & 0.97 & 0.17 & 0.514 & 0.42 \\
\hline C.D. $(P=0.05)$ & NS & 2.73 & 0.47 & 1.451 & 1.18 \\
\hline \multicolumn{6}{|l|}{ Interaction $(\mathbf{M} \times \mathbf{N})$} \\
\hline S.Em. \pm & 0.14 & 1.37 & 0.23 & 0.727 & 0.59 \\
\hline C.D. $(P=0.05)$ & NS & NS & 0.66 & 2.052 & 1.66 \\
\hline C.V.\% & 6.78 & 8.36 & 8.04 & 9.89 & 8.58 \\
\hline
\end{tabular}


Table.4 Interaction effect of $\mathrm{M} \times \mathrm{N}$ on number of tubers per plant of potato (2016-17, 2017-18 and Pooled)

\begin{tabular}{|c|c|c|c|c|c|c|}
\hline \multirow[t]{2}{*}{ Organics } & \multicolumn{6}{|c|}{ Fe and Zn supplementation } \\
\hline & $\mathbf{N}_{1}$ & $\mathbf{N}_{2}$ & $\mathbf{N}_{3}$ & $\mathbf{N}_{4}$ & $\mathbf{N}_{5}$ & $\mathbf{N}_{6}$ \\
\hline & \multicolumn{6}{|c|}{ 2016-17 } \\
\hline $\mathbf{M}_{1}$ & 5.26 & 6.75 & 7.20 & 7.24 & 8.08 & 8.02 \\
\hline $\mathbf{M}_{2}$ & 8.90 & 9.20 & 9.20 & 9.27 & 9.92 & 9.42 \\
\hline S.Em. \pm & \multicolumn{6}{|c|}{0.33} \\
\hline C.D. $(P=0.05)$ & \multicolumn{6}{|c|}{0.96} \\
\hline & \multicolumn{6}{|c|}{ 2017-18 } \\
\hline $\mathbf{M}_{1}$ & 5.65 & 7.21 & 7.85 & 7.92 & 8.14 & 8.09 \\
\hline $\mathbf{M}_{2}$ & 8.57 & 8.66 & 8.64 & 8.68 & 10.00 & 9.54 \\
\hline S.Em. \pm & \multicolumn{6}{|c|}{0.33} \\
\hline C.D. $(P=0.05)$ & \multicolumn{6}{|c|}{0.94} \\
\hline & \multicolumn{6}{|c|}{ Pooled } \\
\hline $\mathbf{M}_{1}$ & 5.46 & 6.98 & 7.53 & 7.58 & 8.11 & 8.06 \\
\hline $\mathbf{M}_{2}$ & 8.73 & 8.93 & 8.92 & 8.97 & 9.96 & 9.48 \\
\hline S.Em. \pm & \multicolumn{6}{|c|}{0.23} \\
\hline C.D. $(P=0.05)$ & \multicolumn{6}{|c|}{0.66} \\
\hline
\end{tabular}

Table.5 Interaction effect of $\mathrm{M} \times \mathrm{N}$ on total tuber yield ( $\left.\mathrm{tha}^{-1}\right)$ and haulm yield ( $\mathrm{q} \mathrm{ha}^{-1}$ ) of potato (Pooled)

\begin{tabular}{|c|c|c|c|c|c|c|}
\hline \multirow[t]{2}{*}{ Organics } & \multicolumn{6}{|c|}{ Fe and $\mathrm{Zn}$ supplementation } \\
\hline & $\mathbf{N}_{1}$ & $\mathbf{N}_{2}$ & $\mathbf{N}_{3}$ & $\mathbf{N}_{4}$ & $\mathbf{N}_{5}$ & $\mathbf{N}_{6}$ \\
\hline & \multicolumn{6}{|c|}{ Total tuber yield (t ha $\left.{ }^{-1}\right)$} \\
\hline $\mathbf{M}_{1}$ & 28.426 & 30.740 & 31.275 & 31.393 & 33.077 & 32.945 \\
\hline $\mathbf{M}_{2}$ & 31.908 & 32.925 & 35.002 & 36.107 & 41.192 & 40.513 \\
\hline S.Em. \pm & \multicolumn{6}{|c|}{0.727} \\
\hline C.D.(P=0.05) & \multicolumn{6}{|c|}{2.052} \\
\hline & \multicolumn{6}{|c|}{ Haulm yield (q ha ${ }^{-1}$ ) } \\
\hline $\mathbf{M}_{1}$ & 16.79 & 17.67 & 17.86 & 17.91 & 19.17 & 18.37 \\
\hline $\mathbf{M}_{2}$ & 16.79 & 18.62 & 20.69 & 21.26 & 25.13 & 22.89 \\
\hline S.Em. \pm & \multicolumn{6}{|c|}{0.59} \\
\hline C.D. $(P=0.05)$ & \multicolumn{6}{|c|}{1.66} \\
\hline
\end{tabular}

\section{Total tuber and haulm yield}

The pooled data given in Table 3 revealed that different treatments of organics and Fe and $\mathrm{Zn}$ supplementation had significant effect on total tuber and haulm yield of potato. An application of $5 \mathrm{t}$ vermicompost $\mathrm{ha}^{-1}$ produced significantly more total tuber and haulm yield of potato as compared to $20 \mathrm{t} \mathrm{FYM} \mathrm{ha-1}$. The magnitude of increase in total tuber and haulm yield of potato with application of $5 \mathrm{t}$ vermicompost ha ${ }^{-1}$ was 15.9 and 16.2 per cent over $20 \mathrm{t} \mathrm{FYM} \mathrm{ha}^{-1}$, respectively. The positive effect of vermicompost on total tuber and 
haulm yield of potato is due to adequate supply of almost all the essential nutrients for growth and development of plants besides, it improves the biological properties of the soil. Another reason for increasing total tuber and haulm yield could be due to presence of microbiota particularly fungi, bacteria and actinomycetes makes it suitable for plant growth and also plant growth regulators, hormones and other plant growth influencing materials produces by microorganisms also present in vermicompost which leads to increase root biomass and better growth and development of plants. Significant improvement in growth and yield attributing characters such as plant height, number of tubers per plant might have contributed to higher total tuber and haulm yield. These results are in confirmation with the findings of Ansari (2008) in potato and Koodi et al., (2017) in sweet potato.

The pooled data presented in Table 3 revealed that the treatments of $\mathrm{Fe}$ and $\mathrm{Zn}$ supplementation had significant on total tuber and haulm yield of potato. An application of organics $2 \mathrm{t} \mathrm{ha}^{-1}$ enriched with $6 \mathrm{~kg} \mathrm{Fe}$ and 4 $\mathrm{kg} \mathrm{Zn}$ being at par with treatment receiving organics $2 \mathrm{t} \mathrm{ha}^{-1}$ enriched with $3 \mathrm{~kg}$ Fe and 2 $\mathrm{kg} \mathrm{Zn}$ produced significantly higher total tuber yield of potato over rest of treatments which was 23.1 per cent higher than that no $\mathrm{Fe}$ and $\mathrm{Zn}$ supplementation. Significantly the highest haulm yield of potato was recorded due to organics $2 \mathrm{t} \mathrm{ha}^{-1}$ enriched with $6 \mathrm{~kg} \mathrm{Fe}$ and $4 \mathrm{~kg} \mathrm{Zn}$. The observed significant increased in total tuber yield of potato due to application of organics $2 \mathrm{t} \mathrm{ha}^{-1}$ enriched with $\mathrm{Fe}$ and $\mathrm{Zn}$ might be due to fact that the soils of experimental plot was deficient in available $\mathrm{Fe}\left(3.80 \mathrm{mg} \mathrm{kg}^{-1}\right)$ and $\mathrm{Zn}\left(0.36 \mathrm{mg} \mathrm{kg}^{-1}\right)$ and its application after enrichment of organics (FYM/vermicompost) improved their availability in soil which might have enhanced yield attributes such as plant height and number of tubers per plant and finally contributed to higher total tuber and haulm yield. These results are in agreement with Ansari (2008) in potato and Koodi et al., (2017) in sweet potato.

The interaction effect of organics $\times \mathrm{Fe}$ and $\mathrm{Zn}$ supplementation $(\mathrm{M} \times \mathrm{N})$ was found significant on total tuber and haulm yield of potato (Table 5) in pooled data. The treatment combination $\mathrm{M}_{2} \mathrm{~N}_{5}$ (5 t vermicompost $\mathrm{ha}^{-1}+$ vermicompost $2 \mathrm{t} \mathrm{ha}^{-1}$ enriched with $6 \mathrm{~kg} \mathrm{Fe}$ and $4 \mathrm{~kg} \mathrm{Zn}$ ) produced significantly higher total tuber yield of potato over rest of the treatment combination except $\mathrm{M}_{2} \mathrm{~N}_{6}$ treatment combination. Significantly the highest haulm yield of potato was recorded under treatment combination of $\mathrm{M}_{2} \mathrm{~N}_{5}$ (5 t vermicompost ha ${ }^{-1}$ + vermicompost $2 \mathrm{t} \mathrm{ha}^{-1}$ enriched with $6 \mathrm{~kg} \mathrm{Fe}$ and $4 \mathrm{~kg} \mathrm{Zn}$ ) over rest of treatment combination.

\section{References}

Ansari, A.A. (2008). Effect of vermicompost on the productivity of potato (Solanum tuberosum), spinach (Spinacia oleracea) and turnip (Brassica campestris). World Journal of Agricultural Science, 4 (3): 333-336.

Channabasana, G., Patil, N.K.B., Patil, B.N., Awaknavar, J.S., Ninganur, B.T. and Hunje, R. (2008). Effect of organic manures on growth, seed yield and quality of wheat. Karnataka Journal of Agricultural Sciences, 21: 366-368.

Desai, D., Patel, B.T., Chaudhary, N. and Thakur, P. (2018). Status of available sulphur and cationic micronutrients in cultivated soils of Banaskantha district of Gujarat. Indian Journal of Agriculture Research, 52 (2): 203-206.

Koodi, S., Singh, S.P., Rolaniya, M.K., Gathala, S. and Choudhary, R. (2017). Effect of NPK, FYM and Vermicompost on growth, yield and quality of sweet potato (Ipomoea 
batatas Lam.). Chemical Science Review and Letters, 6 (21): 495-499.

Meena, M.C., Patel, K. P. and Rathod, D.D. (2006). Effect of $\mathrm{Zn}$ and $\mathrm{Fe}$ enriched FYM on mustard yield and micronutrient availability in loamy sand soil (Typic Haplustert) of Anand. Journal of Indian Society of Soil Science, 54 (4): 495-499.

Patel, S.M., Amin, A.U. and Patel, B.T. (2016). Yield and quality of cumin as influenced by FYM enriched micronutrients. International Journal of Seed Spices. 6 (1): 17-24.

Patel. K.P., Ramani. V.P., Rathod, P.H., Patel, K.C., Kumar, D., Patel, B.K., Parmar, J.K., Jadav, N.J. (2018). $83^{\text {rd }}$ annual convention of Indian Society of Soil Science \& National Seminar on developments in soil science-2018, pp-
76.

Prasad, B. (1999). Conjoint use of fertilizers with organics, crop residues and green manuring for their efficient use in sustainable crop production. Fertilizer News, 44 (5): 67-73.

Rathod, D.D., Meena, M.C. and Patel, K.P. (2012). Effect of different Zn-enriched organics on yields and nutrient uptake under wheat-maize (fodder) cropping sequence in semi-arid region of Gujarat. Indian Journal of Dryland Agriculture Research and Development, 27 (1): 37 42.

Singh, C.B., Singh, S., Singh, H. and Singh V. (2014). Direct and residual effect of nutrient management in wheat-maize cropping sequence. Journal of Indian Society of Soil Science, 62 (2): 126-130.

\section{How to cite this article:}

Neha Chaudhary, B.T. Patel and Sweta A. Patel. 2019. Effect of Iron and Zinc Enriched Organics on Growth, Yield Attributes and Yield of Potato in Loamy Sand. Int.J.Curr.Microbiol.App.Sci. 8(08): 889-896. doi: https://doi.org/10.20546/ijcmas.2019.808.102 